OPEN ACCESS

Edited by:

Adrian Unc,

Memorial University of

Newfoundland, Canada

Reviewed by:

Jan W. Low

International Potato Centre, Kenya

Karl S. Zimmerer,

The Pennsylvania State University

(PSU), United States

*Correspondence:

Margaret A. Lemay lemaym@uoguelph.ca

Specialty section:

This article was submitted to Climate-Smart Food Systems,

a section of the journal

Frontiers in Sustainable Food Systems

Received: 30 January 2021 Accepted: 16 September 2021 Published: 21 October 2021

Citation: Lemay MA, Radcliffe J, Bysouth D and Spring A (2021) Northern Food Systems in Transition: The Role of the Emerging Agri-Food Industry in the Northwest Territories (Canada) Food

\section{Northern Food Systems in Transition: The Role of the Emerging Agri-Food Industry in the Northwest Territories (Canada) Food System}

\author{
Margaret A. Lemay ${ }^{1 *}$, Josalyn Radcliffe ${ }^{2}$, David Bysouth ${ }^{3}$ and Andrew Spring ${ }^{4}$ \\ ${ }^{1}$ Department of Plant Agriculture, University of Guelph, Guelph, ON, Canada, ${ }^{2}$ School of Public Health Sciences, University \\ of Waterloo, Waterloo, ON, Canada, ${ }^{3}$ Department of Integrative Biology, University of Guelph, Guelph, ON, Canada, ${ }^{4}$ Centre \\ for Sustainable Food Systems, Wilfrid Laurier University, Waterloo, ON, Canada
}

This paper reports the findings of an ethnographic study that involved working with local organizations, food advocates, and communities to develop strategies for expanding the nascent Northwest Territories (NWT), Canada agri-food industry. The NWT represents a unique case study in that the fledging agri-food industry has been recognized for its promise in contributing to the core goals of the transitioning NWT food system. The study is guided by two research questions: (1) How is the promise of the emerging NWT agri-food industry framed within the context of the broader food system?

(2) Given this framing of the NWT agri-food industry, how can it contribute to the sustainability of the NWT food system and to the goals of food security, poverty reduction, nutrition, and economic development? Grounded in a food systems approach, we used a correlative, evolutionary SWOT analysis to profile the nascent NWT agrifood industry within the context of the existing NWT food system. Through further thematic analysis, we identify and describe two dominant narratives (agri-food industry business case narrative and agri-food industry implications narrative) and key themes within the narratives based on an adapted food systems framework. The agri-food business case narrative highlights discourse articulating the business or commercial viability for a local agri-food value chain to function, evolve, and expand. The agri-food industry implications narrative envisions the ways in which the emerging NWT agrifood industry may interact within the existing NWT food system, highlighting potential environmental, social, cultural, and political implications of an expanding commercialbased agri-food value chain. Within the two narratives, certain subcomponents of the NWT agri-food system appear to be more prevalent, including climate, soil, and ecosystems, policy/regulations/governance, socio-cultural norms, knowledge, inputs, finance, production, and consumption. We make policy and practice recommendations for co-designing an agri-food industry that serves the multiple goals of the NWT food system. As an exploratory, descriptive-structural analysis the study provides a critical empirical basis for future in-depth, fully integrated synthesis of the complex social, cultural, economic, political, and ecological dynamics shaping Northern food systems in transition.

Keywords: agri-food industry, transitions, food security, economic development, poverty reduction, northern food systems, Northwest Territories (Canada) 


\section{INTRODUCTION}

For millennia, food systems across Canada's northern regions have depended on the land, waters, plants and wildlife that are abundant in northern ecosystems. Traditional foods have been gathered from the land through hunting, trapping, fishing, harvesting and other activities that continue to be the basis of the traditional economy and livelihoods and are fundamental to the culture and the social connections in Indigenous communities. Over time, these traditional food systems have been degraded through climate change, resource extraction and the widespread impacts of colonization, including the transition to settlements through government policies and programs and the introduction of the wage-based economy (Power, 2008; Council of Canadian Academies, 2014; Wilson et al., 2020). As a consequence, over the past decades there has been a transition in traditional food systems in Canada's North, such as the Northwest Territories (NWT) and around the globe, moving away from traditional food sources to ultra-processed foods purchased from stores (imported market foods) (Popkin, 2002; Kuhnlein and Receveur, 2007; Damman et al., 2008; Kuhnlein, 2015; Lamalice et al., 2018). High transportation costs, food spoilage, and limited competition through distribution and retail options means that much of the food shipped into northern regions is inaccessible to a large portion of the population resulting in alarming rates of moderate to severe food insecurity (Council of Canadian Academies, 2014; Galloway, 2014; Tarasuk et al., 2016). Furthermore, northern food systems are facing increasing expectations to serve an expanded range of complex policy priorities, such as food sovereignty, poverty reduction, climate change adaptation and mitigation, sustainability, equity, social justice, natural resources management and economic development (GNWT, 2017).

In response to these challenges, many northern regions are envisioning new and expanded roles for a local agrifood industry that includes commercial production, processing and distribution capacity (Government of Newfoundland and Labrador, (n.d.); Serecon, 2014; Government of the Yukon, 2016; GNWT, 2017; Soppela, 2018; City of Yellowknife, 2019). Within the context of northern food systems, a local agri-food industry is an integral component that compliments traditional foods and reduces the reliance on imported market foods. A local agrifood industry serves as an economic sector of the jurisdiction where it operates. Along with farmers, the agri-food industry is comprised of a variety of businesses that deal with every aspect of producing, processing, manufacturing, and distributing food, which represents the agri-food value chain.

Historically, a local or regional agri-food industry has been a minor economic sector in most northern regions, playing a relatively limited role in most northern food systems (Gerlach and Loring, 2013) and the regional economy (Unc et al., 2021). More recently, the convergence of various factors is making the promise of northern agriculture on a commercial scale a reality. Climate change is creating "climate-driven agricultural frontiers," areas that are becoming or will become climatically suitable for growing a wider range of crops (Hannah et al., 2020). Advances in agricultural science and technology are making northern agriculture a more viable commercial venture. As local production scales up, the opportunities for a local value-chain (processing and distribution) also increase. However, both the benefits and the tradeoffs of northern agri-food expansion need to be further evaluated and explored at a community scale to ensure that new or expanded local agri-food industries contribute to and support a resilient and sustainable food system (Tendall et al., 2015; Unc et al., 2021).

While compelling, the promise of a local agri-food industry to contribute to the complex needs of northern food systems is not without risks and challenges (Simba and Spring, 2017; King et al., 2018; Hannah et al., 2020). The dramatic shift in agriculture production through industrialization in the 20th century that resulted in significant increases in productivity and yields has had negative impacts on ecosystems, water, soil and climate worldwide (Patel, 2013; IPES-Food, 2016; Hetherington, 2020). The resulting agri-food system that still dominates today has also had negative impacts on food security, local economies and health as high calorie and processed commodity crops, such as corn and rice have replaced many nutrient-rich foods in diets around the world (Patel, 2013; IPES-Food, 2016; Hetherington, 2020).

Current and potential northern agriculture regions are ecologically, politically, and culturally distinct from the more well-developed agricultural regions of the South. The benefits of developing and expanding new agricultural landscapes in the North must be considered against the potential undesirable consequences (King et al., 2018; Hannah et al., 2020). One of the major trade-offs from expanding or establishing agricultural regions in the North is the potential release of soil carbon from clearing and cultivating previously undisturbed lands as this has implications for achieving climate change targets (Guo and Gifford, 2002; Hannah et al., 2020; Unc et al., 2021). Furthermore, northern ecosystems provide a myriad of unique and essential ecosystem services that sustain the northern ecosystem and are critical to Indigenous culture and traditions and could be negatively impacted by land conversion to agricultural production (Powlson et al., 2011; Hannah et al., 2020; Bélisle et al., 2021). Socio-political implications are largely unexplored; yet, are equally as important and complex as the ecological and require the engagement of Indigenous and local community stakeholders to balance the potential trade-offs of expanding agriculture in the North (Spring et al., 2019; Hannah et al., 2020). In addition, there is an opportunity for increased local production to create new livelihoods in developing economies, such as the NWT (Tomich et al., 2019). Finally, the opportunity for entrepreneurship and job creation across the value chain as a result of a developing agri-food industry may support a reduction in poverty rates, as has been shown in other agri-food systems (Christiaensen et al., 2011). The development of a resilient local agri-food value-chain will depend upon balancing the benefits and tradeoffs associated with agricultural expansion into these highly complex northern communities.

In their efforts to define a shared vision for the future of commercial-scale agri-food activities and to make policy, governance and infrastructure decisions about the new and/or expanding role of an agri-food industry in their regional food systems, northern stakeholders need a better understanding of 
the underlying structure and dynamics of complex food systems (Hodbod and Eakin, 2015; Caldwell et al., 2018). Moreover, with relatively underdeveloped, but promising local agri-food industries, there is a clear, need for relevant, local knowledge and a better understanding of the challenges, opportunities, drivers, and implications of supporting the growth and expansion of commercial agri-food activities.

Recent research has highlighted the importance of a systems-based approach for studying the complex linkages, dynamics and interactions within a food system, including the actors, biogeophysical components, socio-economic context, and the multiple, sometimes competing priorities of northern food systems (Wittman et al., 2017; Food and Agriculture Organization of the United Nations, 2018; Béné et al., 2019; Brouwer et al., 2020). Embedding food systems analyses within a systems framework has proven to be an effective approach for capturing this inherent complexity and for helping food systems actors to develop solutions for managing complex food systems that are expected to meet diverse goals (Bacon et al., 2012; Lamine, 2014; Hodbod and Eakin, 2015; Spring et al., 2018; Oteros-Rozas et al., 2019). A necessary first step to this systems approach is to understand the individual components of the food system (Brouwer et al., 2020). This paper focuses on that first step using the emerging agri-food industry in the NWT and its role the broader food system as a case study.

In the NWT, the agri-food industry is gaining increasing attention from northern stakeholders as part of a solution toward building a sustainable, adaptive food system that responds to critical policy imperatives, including poverty reduction, food security, nutrition, and economic development (GNWT, 2017). As a nascent and fledgling economic sector in the NWT, the agrifood industry was recently identified as an emerging opportunity for the NWT economy (Economic Opportunities Strategy Governance Committee, 2013). The promising role of the agrifood industry in the NWT represents, in essence, a transition of a food system reliant on traditional and imported market foods to an agri-food system-where a local value-chain (commercialscale agriculture production, processing and distribution) is expected to play a more important role in the food system. The NWT is a rare case in which a local agri-food industry, as an economic sector, is largely underdeveloped. However, stakeholders in the NWT have acknowledged the "promise" of a fledging territorial agri-food industry for meeting various policy and social priorities. As such, the emerging NWT agri-food industry is an excellent case for a systems-based analysis of a food system in transition. It offers a unique opportunity for studying a nascent agri-food industry within the context of an existing food sytem to gather baseline data for gaining critical insights and providing strategic recommendations for managing the complex goals of a northern food system in transition.

A historical review of agriculture in the NWT provides important context for understanding both the present realities and future implications. Subsistence agriculture has a long history in the NWT beginning with its introduction by early settlers, fur traders and missionaries [Cardinham Text and Creations, (n.d.)]. However, its integration into residential schools has left some negative associations with agriculture among Indigenous communities (Simba and Spring, 2017). In the early 1900's the federal Department of Agriculture established a small network of Dominion Experimental Farm Substations in several communities across the NWT. By 1943 there were 252 acres under cultivation [Cardinham Text and Creations, (n.d.)]. During this time, the federal government also supported the resource extraction industry through subsidies for railways, highways, airports, and hydroelectric developments around key mining areas. This infrastructure, coincidentally, made importing food into the NWT much easier (Johnston, 2018). Building a territorial agri-food industry lost momentum due to competition from imported foods from the South. As well, despite recommendations by the Department of Agriculture in 1966 to introduce a regional Department of Lands and Resources in the NWT, no action was taken, and the experimental farms were shut down in 1970 [Cardinham Text and Creations, (n.d.)].

Agriculture has continued in the NWT, although at a smaller, uncoordinated scale, for decades. Scaling up local commercial food production, processing and distribution is key to building a thriving agri-food industry that supports a resilient territorial food system (GNWT, 2017). Commercial-scale agriculture is represented throughout the NWT with at least one commercial operation in each of the five regions of the Territory (GNWT, 2017). Currently, commercial agriculture in the NWT includes eggs, greenhouse vegetables, potatoes, and market gardens (GNWT, 2017). Farmers markets in several communities support small-scale commercial agriculture and are relied upon to nurture future industry growth yet face obstacles in meeting local demand (Radcliffe et al., 2021). Value-added activities are limited by the shortage of local produce. Nonetheless, the agri-food industry is becoming an important element of the NWT food system, as well as its economy (GNWT, 2017). It was identified as one of the NWT's emerging economic sectors with the potential to increase economic opportunities (Economic Opportunities Strategy Governance Committee, 2013). Understanding its future and how best to integrate it with other parts of the food system, including traditional foods and livelihoods and imported market foods, is a priority for policymakers, community leaders, sustainable food system advocates, and stakeholders in the NWT agri-food industry.

The research presented in this paper is part of a larger ongoing initiative, Northern Agriculture Futures (NAF), led by the Ka'a'gee Tu First Nation in Kakisa, NWT in partnership with NWT communities, academic partners and local organizations. NAF aims to address barriers to the production of local food in communities across the South Slave and Dehcho regions of the NWT and to build a broad network of local food actors to discuss the future of agriculture. As many communities are turning to local food production, NAF has led to multiple discussions across the region about the benefits, trade-offs and barriers to scaling up local food production, including commercial agri-food activities. This paper reports the findings of one study within the NAF initiative that involved working with territorial organizations, local food advocates and agri-food entrepreneurs to develop strategies for expanding the NWT agri-food industry as an emerging but critical element of the NWT food system. It is an exploratory 
study, mostly descriptive and structural in nature. We argue that a descriptive-structural analysis (what a food system is) provides a necessary empirical basis for future in-depth, normative-strategic analyses (how a food system should be) of the dynamics shaping northern agri-food systems (Neven, 2014).

Grounded in a food systems approach (Wittman et al., 2017; Food and Agriculture Organization of the United Nations, 2018; Brouwer et al., 2020), we used a correlative, evolutionary SWOT analysis (Vlados, 2019; Vlados and Chatzinikolaou,
2019) to profile the fledgling NWT agri-food industry within the context of the existing NWT food system. Through further thematic analysis, we identify and describe dominant narratives and key themes within the narratives that frame important constraints and drivers shaping the future of the NWT agri-food industry and its potential to contribute to the core goals of the NWT food system: sustainability, food security, nutrition, poverty reduction and economic development. We make policy and practice recommendations for building an agri-food industry that serves the multiple

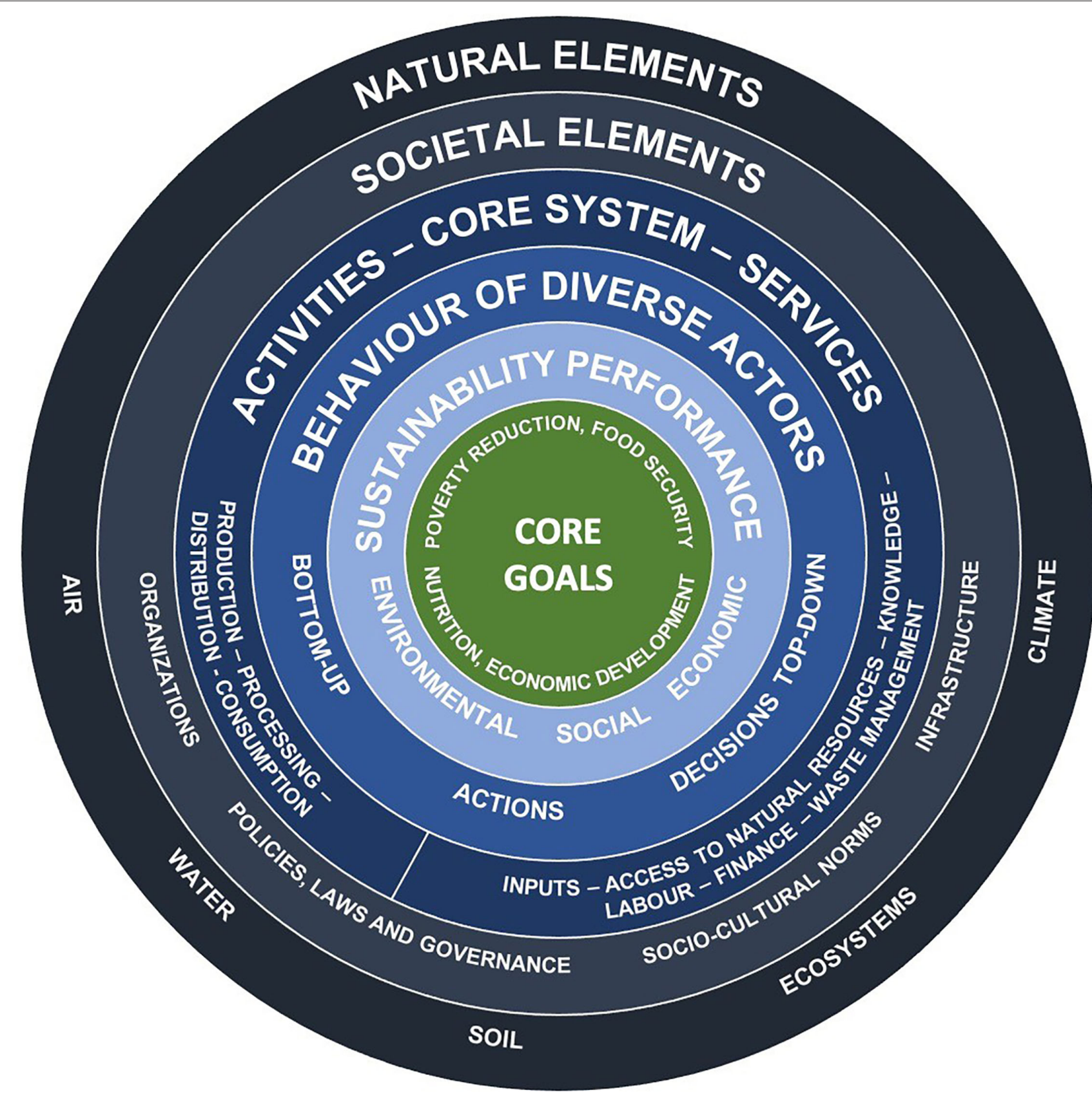

FIGURE 1 | Adapted Food Systems Framework. (Source: Food and Agriculture Organization of the United Nations. Adapted with permission) 
goals of the NWT food system. The study is guided by two research questions:

1) How is the promise of the emerging NWT agri-food industry framed within the context of the broader food system?

2) Given this framing of the NWT agri-food industry, how can it contribute to the sustainability of the NWT food system and to the goals of food security, poverty reduction, nutrition, and economic development?

The paper is organized as follows. The next section (2) "Materials and Methods," outlines our conceptual framework and describes the study design and methods. In Results we report our findings based on our conceptual framework, which address our first research question. In the discussion (Discussion), we answer our second research question by focusing on the central goals of the food system as defined in our conceptual framework (sustainability, food security, nutrition, economic growth and poverty reduction. In Conclusion we conclude with policy recommendations and suggestions for future research.

\section{MATERIALS AND METHODS}

\section{Conceptual Framework}

The food systems approach is the foundation of this analysis as northern agri-food systems are fundamentally shaped by complex, interdependent natural and social elements (Chapman et al., 2017; Food and Agriculture Organization of the United Nations, 2018; Béné et al., 2019; Brouwer et al., 2020). At the core of this approach is a respect for the interactions between the social, cultural, and ecological and the critical need for these intersections to be integrated into an analysis focused on supporting sustainable food systems and transitions (Bacon et al., 2012). We have operationalized our systems approached by adapting the FAO sustainable food systems wheel (Food and Agriculture Organization of the United Nations, 2018) to represent the NWT food system (Figure 1; Table 1). Our adapted food systems framework maintains a focus on the complete food system, "taking into account all the elements, their relationships, and related effects... [in] an intricate web of interlinked activities and feedbacks" (Food and Agriculture Organization of the United Nations, 2018, p. 2), at the same time reflecting the unique aspects of the NWT food system. We use our adapted food systems framework (FSF) to structure and organize our analysis.

The FSF consists of six concentric rings (Figure 1; Table 1). It is centered around the core goals or outcomes of a food system: nutrition, food security, poverty reduction, and economic development. The outcomes are dependent on the sustainability of the system, which encompasses the three dimensions of sustainability: social, ecological, and economic. The third inner ring (behavior of diverse actors) highlights the importance of agency in shaping the sustainability performance and outcomes of the system. Actors range from the bottom-up grassroots actions of communities, farmers, agri-food entrepreneurs to the top-down decisions of policy makers and local governments. The actions and decisions of diverse stakeholders take place within the "structure" of the socio-ecological system, which is represented by the three outer rings of the FSF, and includes the core agrifood system (activities and services), as well as the societal context and natural environment. The core system is comprised of two tightly linked subsystems (activities and services). The core system-activities represent the traditional segments of an agri-food industry, often referred to as the agri-food value chain: production, processing, distribution, consumption and waste management. The second subsystem encompasses the matrix of services that support and shape the core system activities and include: access to natural resources, inputs, knowledge, labor, and finance. The core system is embedded in an external milieu represented by the societal context and the natural environment. The subcomponents of societal context include organizations, policy, regulation and governance, infrastructure, and socio-cultural norms. The natural environment is comprised of climate, water, soils, ecosystems and air subcomponents. The most critical feature of our adapted food system framework is the interdependence among the components (the rings) in shaping each other and ultimately the desired outcomes of the food system (sustainability, food security, nutrition, poverty reduction and economic development) (Wittman et al., 2017; Food and Agriculture Organization of the United Nations, 2018).

\section{Study Design and Methods}

A naturalistic inquiry approach using ethnographic techniques was used to observe the NWT agri-food system transition process through the actions and discourses of stakeholders in the "real world" in "real time" (Stake, 2010). Following standard ethnographic methods (O'Reilly, 2012), the dataset for the study was generated from participant observations and informant input through interaction and engagement with stakeholders, augmented by document review and field notes. Participant observations included a variety of interactions with partners and stakeholders, such as phone calls, meetings (face to face and virtual platforms), emails, community engagement sessions, and a facilitated strategic planning session of the NWT Food Network Board of Directors held in Hay River in March 2020. Informant input from stakeholders and community partners provided details and clarifications of the participant observations, as well as background and historical information about the NWT food system and agri-food industry. Participant observations and informant input took place from August 2019 to October 2020. A variety of historical records and current documents were analyzed, including government, stakeholder and community policies, strategic plans, reports, project summaries, websites, media reports and research proposals. Many of these documents provided detailed profiles and history of the NWT agri-food industry and commentary on its promise for supporting and advancing various government policy priorities. Extensive field notes of the participant observations, informant input and document review were taken throughout the 15-month study and informed the analysis. While this study is indirectly informed by participation and engagement of Indigenous partners, embedded in reviewed documents, it is not a replacement for direct engagement and inclusion, which was limited in this study. Further study into the ways Indigenous communities shape the agri-food industry and the broader NWT food system today and 
TABLE 1 | Description of each component (ring) and its associated subcomponents of the adapted food systems framework (Figure 1) with SWOT results.

\begin{tabular}{|c|c|c|c|}
\hline Component & Subcomponents & SWOT* Results & Description \\
\hline Core goals & $\begin{array}{l}\text { Poverty Reduction Food Security Nutrition Economic } \\
\text { Development }\end{array}$ & & $\begin{array}{l}\text { The NWT has identified these outcomes as the core goals of } \\
\text { its food system. }\end{array}$ \\
\hline Sustainability performance & Environmental Social Economic & & $\begin{array}{l}\text { The performance of a food system based on the three } \\
\text { dimensions of sustainability determines the success in } \\
\text { achieving the core goals. }\end{array}$ \\
\hline Behavior of diverse actors & $\begin{array}{l}\text { Policymakers Food systems advocates Communities } \\
\text { Industry stakeholders }\end{array}$ & & $\begin{array}{l}\text { Diverse actors include both bottom-up and top-down } \\
\text { actions and decisions that shape the performance of the } \\
\text { food system. Actors' behaviors are mediated within the } \\
\text { broader structural components of the food system: the core } \\
\text { system, societal context and natural environment. }\end{array}$ \\
\hline \multirow[t]{5}{*}{ Core system: activities } & Production & $\mathrm{S}, \mathrm{O}$ & $\begin{array}{l}\text { The core system activities represent the pathway through } \\
\text { which food products are produced. }\end{array}$ \\
\hline & Processing & $\mathrm{O}$ & \\
\hline & Distribution & $\mathrm{S}, \mathrm{W}, \mathrm{O}$ & \\
\hline & Consumption & $\mathrm{S}, \mathrm{O}$ & \\
\hline & Waste management & & \\
\hline \multirow[t]{5}{*}{ Core system: services } & Access to natural resources & $\mathrm{T}, \mathrm{O}, \mathrm{W}$ & $\begin{array}{l}\text { The matrix of services that directly support the core system } \\
\text { activities. }\end{array}$ \\
\hline & Labor & $\mathrm{T}$ & \\
\hline & Inputs & $\mathrm{O}$ & \\
\hline & Knowledge & S, W, O & \\
\hline & Finance & W & \\
\hline \multirow[t]{4}{*}{ Societal context } & Organizations & & $\begin{array}{l}\text { The social context represents the external social dimension } \\
\text { of a socio-ecological system and its influence in shaping the } \\
\text { core system, actors' behaviors, sustainability performance } \\
\text { and the core goals. }\end{array}$ \\
\hline & Policies, laws, regulations & $\mathrm{S}, \mathrm{W}, \mathrm{O}, \mathrm{T}$ & \\
\hline & Infrastructure & & \\
\hline & Socio-cultural norms & $\mathrm{S}, \mathrm{W}, \mathrm{O}, \mathrm{T}$ & \\
\hline \multirow[t]{5}{*}{ Natural environment } & Air & & $\begin{array}{l}\text { The subcomponents of the natural environment interact to } \\
\text { provide critical ecosystem services that reverberate } \\
\text { throughout the entire food system. In northern food systems } \\
\text { there is an enduring connection between the natural } \\
\text { environment, people and communities, health and } \\
\text { well-being. }\end{array}$ \\
\hline & Soil & $\mathrm{T}$ & \\
\hline & Ecosystem & $\mathrm{T}$ & \\
\hline & Water & & \\
\hline & Climate & $\mathrm{T}$ & \\
\hline
\end{tabular}

"S, strength; W, weakness; O, opportunity; T, threat.

into the future are underway as part of the NAF initiative, of which this study is a part.

We applied a qualitative analysis to the dataset using QSR Nvivo 12 in a two-stage process. First, the dataset was reviewed and deductively coded to the structural subcomponents of the FSF (Figure 1; Table 1) and as a strength, weakness, threat or opportunity using a correlative and evolutionary SWOT analysis (Vlados, 2019; Vlados and Chatzinikolaou, 2019) to structure and organize the data. A correlative and evolutionary SWOT analysis addresses the limitations of a conventional SWOT by acknowledging that "socioeconomic forces and factors are strongly and systematically related to each other" and that transitions are a "gradual process of change, accumulation of results and path-dependent development of all socioeconomic forces and actors" (Vlados, 2019, p. 353). In other words, adopting a correlative and evolutionary SWOT analysis fits with our food systems theoretical grounding.

The first stage analytical process produced "data extracts," chunks of text abstracted from the dataset (Dey, 1993). The data extracts, now coded under an FSF subcomponent and SWOT, were subjected to a second stage thematic analysis. Following an inductive thematic analysis approach (Braun and Clarke, 2006), the data extracts were read and analyzed to identify key themes that characterized the discursive framings of the FSF subcomponents in the context of the promise of the NWT agrifood industry. The thematic analysis was instrumental in giving 
the results of the SWOT analysis a more nuanced interpretation. Given our qualitative approach to the research, we did not apply a quantitative basis for identifying the themes reported in the findings (e.g., the number of references coded to "access to natural resources"). Such "counting" would not provide the type of "rich description" that a thematic analysis of qualitative data provides (Dombroski et al., 2020).

\section{RESULTS}

The results of the SWOT analysis are summarized in Table 1. The SWOT analysis was applied only to the structural elements of the FSF, which comprise the outer three rings: Core system activities and services, natural environment, and societal context (Figure 1). Not all the subcomponents of the FSF were captured in the dataset. Missing from the dataset were references to waste management, organizations, infrastructure, air, and water.

Based on our analysis, we identify two dominant narratives that frame the future of the agri-food industry within the NWT food system: the agri-food industry business case narrative and the agri-food industry implications narrative. The agrifood business case narrative frames the FSF subcomponents as constraints and/or drivers of the growth and development of the NWT agri-food industry. This narrative highlights the challenges and the opportunities for establishing and maintaining a new economic sector in the NWT. It speaks to the current nature of the FSF subcomponents and their potential impacts on the business or commercial viability for a local agri-food value chain to function, evolve and expand. The agri-food industry implications narrative emphasizes the potential impacts or implications of the agri-food industry on the subcomponents of the NWT food system. This narrative envisions the ways in which the emerging NWT agri-food industry may interact within the existing NWT food system. It highlights the potential environmental, social, cultural and political implications of an expanding commercial-based agri-food value chain. Within both narratives, while there are competing goals and interests, there appears to be a shared vision for an agri-food industry that provides "food from the NWT for the NWT."

Certain subcomponents of the NWT agri-food system appear to be more prevalent within the two narratives. Within the natural elements these prevalent subcomponents include climate, soil, and ecosystems. The more prevalent subcomponents of the social context include policy/regulations/governance, and socio-cultural norms. Knowledge and inputs were predominant subcomponents of the core systems services, while production and consumption were outstanding subcomponents of the core system activities (Table 2). We also note discursive patterns (themes) that frame these more prevalent subcomponents of the FSF in multiple, interdependent, and sometimes conflicting ways (Table 2). We present our findings by describing the key themes that frame the prevalent subcomponents within the context of the two narratives. In the discussion (Discussion), we link the our findings to the core goals of the FSF (two inner circles) (sustainability, food security, nutrition, poverty reduction and economic development) and highlight the potential implications for the emerging NWT agri-food industry in contributing to those goals.

\section{Natural Environment}

Both narratives are represented in the natural environment component discourse. A point of consensus in the discourse among stakeholders was the inherent and essential role of the natural environment in the lives of the people of the NWT and its food system. Any future agri-food industry would be expected to respect and strengthen this relationship. The Premier, Bob McLeod articulated the relationship in the NWT Sustainable Land Use Framework (Government of the Northwest Territories, 2014):

Land is life. It is the link to our past. Many people draw their spiritual and cultural identity from the land. It has provided food and materials to sustain the people of the Northwest Territories (NWT) for hundreds of years, and it is the key to the future... (n.p.).

Climate and soil tend to dominate the natural environment discourse about the future of agriculture, with ecosystems having a less prominent, but salient presence.

\section{Climate}

Climate is generally framed in two ways: climatic conditions, which is part of the agri-food business case narrative and climate change, which is reflective of the agri-food industry implications narrative.

\section{Climatic Conditions}

The climatic conditions are a constraint to the future of agricultural production in the NWT. The climate is highly variable with regional differences dictating the types of production (crops, livestock) that may occur in different regions. The growing season, as defined by the number of frost-free days, ranges from 40 to 100 days (Serecon, 2014). The amount of daylight during the growing season is comparatively high, with 16-19h of daylight available during the growing season in the southern NWT and up to $24 \mathrm{~h}$ of daylight during the growing season in more northern communities (Serecon, 2014). Daylength is considered as a mediating factor that can compensate for the relatively low mean temperatures. These climatic factors (low mean annual temperature, length of the growing season and the amount of daylight) contribute to the growing degree days and crop heat units available for crop growth in northern communities, which are generally considered to limit the range of the crops that could be grown in the NWT. For example, the Hay River Sustainable Agriculture Plan (Serecon, 2014) highlights this discourse about climatic conditions: "The primary limiting factor for crop selection is the low heat units available for crop growth... However, the long daylight does make up for the short growing season for many other crops." (p. 15)

Another critical aspect of the climate that has an impact on the future of agriculture is precipitation, which is generally regarded as inadequate for meeting the needs of most crops. Low levels of precipitation are a potential barrier to expanding commercial scale agriculture. While irrigation is a possible solution, there are concerns of over potential impacts on water 
TABLE 2 | Key themes framing the dominant subcomponents of the adapted foods systems framework.

\begin{tabular}{|c|c|}
\hline Framework Subcomponent & Themes \\
\hline \multicolumn{2}{|l|}{ Natural Elements } \\
\hline Climate & $\begin{array}{l}\text { - climate as constraining future of agriculture } \\
\text { - climate change driving transition to agri-food system } \\
\text { - Agriculture as a climate change adaptation and mitigation strategy } \\
\text { - Agriculture contributing to climate change }\end{array}$ \\
\hline Soil & $\begin{array}{l}\text { - limited soil suitable for agricultural production } \\
\text { - requires amendments due to low levels of essential nutrients } \\
\text { - important component of the terrestrial ecosystem, reflecting the health of the ecosystem }\end{array}$ \\
\hline Ecosystems & - risks from commercial agriculture to biodiversity, wildlife health, new invasive species \\
\hline \multicolumn{2}{|l|}{ Societal Context } \\
\hline Policy, regulations, governance & - current policy/governance system constrains future of agri-food industry due to lack/absence of agri-food policy/regulations \\
\hline Socio-cultural norms & $\begin{array}{l}\text { - cultural importance of food and community-based gardening } \\
\text { - } \text { promise of agri-food industry to open new sources of traditional knowledge and new agri-food cultural practices }\end{array}$ \\
\hline \multicolumn{2}{|l|}{ Core System-Services } \\
\hline Knowledge & $\begin{array}{l}\text { - framed as both weakness and opportunity } \\
\text { - multiple framings: innovation, research, training, expertise, capacity building, western science and traditional knowledge } \\
\text { - sharing knowledge }\end{array}$ \\
\hline Inputs & $\begin{array}{l}\text { - framed as weakness and opportunity } \\
\text { - lack and high costs }\end{array}$ \\
\hline Access to natural resources & $\begin{array}{l}\text { - lack of infrastructure (e.g., roads) } \\
\text { - land unavailable for agriculture production } \\
\text { - uncertainty regarding land ownership }\end{array}$ \\
\hline \multicolumn{2}{|l|}{ Core System - Activities } \\
\hline Production & $\begin{array}{l}\text { - general sense of hope and anticipation about future of agri-food industry } \\
\text { - diverse range of crops successfully grown } \\
\text { - entrepreneurial opportunities support economic development and job creation } \\
\text { - high costs of production threat to consumer demand and competitiveness of NWT agri-food industry to compete with } \\
\text { imported food } \\
\text { - poor supply-chain relationships }\end{array}$ \\
\hline Consumption & $\begin{array}{l}\text { - consumer demand for local food strong and increasing } \\
\text { - consumer preferences for diverse } \\
\text { - consumer resistance to higher prices of local food } \\
\text { - consumer support for various market channels (farmers' markets, farm gate and local retailers) }\end{array}$ \\
\hline
\end{tabular}

quality. According the GNWT (2017), "the NWT experiences low levels of annual precipitation. Irrigation may be a consideration that enhances production; however, care is needed to protect and access uncontaminated water supplies through the proper use of water systems" (p.15).

\section{Climate Change}

The second framing of climate is climate change as a driver of the transition of the food system to integrate a local agrifood industry. The impacts of climate change threaten the sustainability of the food system, as well as the food security and sovereignty of NWT communities in several ways and contribute to the challenges of maintaining traditional ways of life (e.g., availability and accessibility of traditional foods) (Simba and Spring, 2017; City of Yellowknife, 2019). Agriculture shows promise as not just a climate change adaptation strategy. Some stakeholders envision agriculture as a climate change mitigation strategy - as a way to slow the pace of climate change. This discourse contrasts with concerns over the risks of commercial-scale agriculture in contributing to climate change. These concerns are also noted in the discourse framing access to natural resources.

\section{Soil}

Soil is predominantly framed as a constraint to the promise of the agri-food industry. There is limited soil that is suitable for agricultural production in many regions of the NWT due to underlying geological conditions (Cook, 2017) and low levels of essential nutrients such as nitrogen:

In almost every community, the soil requires some type of amendment... In almost all cases, there is a need to add nutrients, which is most commonly being done through the addition of manures. The availability of manure is also quite limited, resulting in much of the required manure being imported from outside the territory. There is some manure ... but these are of limited quantities and still require considerable transport especially for northern regions [Government of the Northwest Territories (Industry Tourism and Investment), 2015, p. 12].

Soil contamination from past mining activities is a concern particularly in Yellowknife:

Although garden produce has been found to contain arsenic, there has been no evidence to date that demonstrates garden vegetables grown within the City of Yellowknife, N'dilo and Dettah pose a risk 
for human consumption. Imported soil can be used as a precaution (City of Yellowknife, 2019, p.23).

There is a complex relationship between soil and other subcomponents of the agri-food system, such as access to natural resources, inputs, and knowledge. This interdependence across the broader components of the food system framework is illustrated by the findings reported from the community engagement sessions for the NWT Agriculture Strategy [Government of the Northwest Territories (Industry Tourism and Investment), 2015]: “[a] common concern raised was that individuals are not aware of the location of the best soils in their area, their ability to access those soils, or the ability to get accurate soil tests completed" (p. 12).

\section{Ecosystems}

The discourse around ecosystems is illustrative of the agrifood industry implications narrative. Expansion of commercial agriculture poses risks to biodiversity from unsustainable agricultural practices. There are risks from the potential introduction of invasive species and loss of habitat due to land clearing and the risk of disease transmission from livestock to wildlife. This is a compelling narrative, given the strong cultural links between traditional food systems and northern ecosystems. Another defining characteristic of the ecosystem discourse is that it is acknowledged by most stakeholders. There is consensus that protecting the unique northern ecosystem is a priority and that commercial-scale agricultural practices must reflect this value. The GNWT Agriculture Strategy highlighted the importance of developing sustainable agriculture practices that conserve and sustain the northern ecosystem:

\begin{abstract}
...To date, northern agriculture and agri-foods productions has had minimal impact on wildlife and wildlife habitats. However, biodiversity can be threatened with unsustainable agriculture practices such as the cultivation of uniform crops, the introduction of pests or diseases such as anthrax or rabies, water pollution and /or soil degradation. Other possible threats to biodiversity include invasive species (plants, animals, insects), the potential for genetic pollution, direct damage to wildlife and wildlife habitats and risks inherent in the transfer of disease from wildlife to domestic animals and from livestock to wildlife. This Strategy recognizes that additional work is needed, in partnership with key stakeholders to ensure the wildlife friendly agricultural practices are followed. These practices will be outlined in regulatory and guidance documents... (GNWT, 2017,p. 14).
\end{abstract}

\section{Societal Context}

The societal context has a strong presence in how stakeholders perceive the future of the NWT agri-food industry, its role in, and implications for the food system. The two subcomponents within societal context that dominate the discourse on the promise of the NWT agri-food industry include policies, regulation, and governance and socio-cultural norms.

\section{Policy, Regulations and Governance}

As part of the agri-food business case narrative, policy, regulation and governance are a critical driver shaping the future of the agri-food industry in the NWT. While framed as a strength, weakness, opportunity, and threat, in general, the current policy/governance system is seen as constraining the future of the agri-food industry. One point of consensus among stakeholders is the absence of agriculture policies and regulations. While many see absence of agriculture policy and regulation as strength or opportunity, it is also recognized that policies and regulations are necessary to protect the public health and safety, the fragile NWT ecosystem, as well as supporting the competitiveness of the nascent agri-food industry. Food safety regulations are proving to be a contentious issue among some food system actors, who perceive them to be a barrier to food security and food sovereignty. The absence of agriculture regulations is perceived to create a less restrictive environment for the agrifood industry relative to other highly regulated industries, such as mining. According to a producer at the NWT Food Network Strategy Session, the lack of regulations is an opportunity for "industry to build a regulatory [framework] in partnership with territorial/provincial colleagues."

Many stakeholders spoke of confusion in accessing information about regulations and a lack of clarity. The need for agriculture policies and regulation has been acknowledged at both the community and territorial level. For example, the GNWT Agriculture Strategy (GNWT, 2017) highlights the weakness of the current policy framework to support the growth of the agri-food industry:

In order to build an agriculture sector, regulations, legislation and policies are required at all levels of government, to enable it to grow and function. Under current legislation, the NWT's agriculture sector has very little room to grow and a supporting agriculture policy framework has yet to be developed (p.9).

A review of current legislation has identified a number of gaps specific to agriculture. Additional regulations are needed to meet the needs of producers involved in areas ranging from animal handling to product marketing (p.10).

Existing policies and regulations, which have been developed for other sectors and applied to agriculture are a limitation to the growth and development of the industry. For example, in the absence of water regulations for agriculture, regulations designed for the mining sector are being applied. The need for policies specific to agriculture was highlighted in the Hay River agriculture strategy:

Consideration should also be given to specifically considering agriculture when determining the zoning for new parcels of land. There is always the potential for conflict when adjacent lands are used for residential purposes and for agriculture (however small the area). (Serecon, 2014, p.29)

Moreover, some stakeholders are concerned that the existing policy infrastructure does not reflect the unique needs, circumstances, and realities of northern communities, in particular, Indigenous communities. Current food system policies are seen as a barrier to self-determination, food sovereignty and community economic development: 
...many federal laws are imposed on the North, without consideration for the unique conditions and circumstances of the people and communities who live there. The current existing legislative and regulatory framework is an impediment to harvesting, selling and sharing country/traditional food... food safety regulations... and practices were considered to have a negative effect on access to country/traditional foods in communities. (The Gordon Foundation, 2017, p.10-11)

This quote highlights another weakness of the existing policy infrastructure, which is the lack of regulatory, inspection and enforcement capacity. This is a concern at both the territorial and community level: "The regulatory capacity of both the GNWT and the Town of Hay River would likely be insufficient for rigorous regulatory enforcement" (Serecon, 2014, p. 34)

Other policy concerns raised by stakeholders include agriculture labor laws, food safety and health regulations, land title and land use policy. Land use policy is a major issue that has been identified by many stakeholders, including the Territorial government: "Permanent resolutions of land issues are complex but need to be resolved in order to move the sector forward" (GNWT, 2017, p. 29). The discourse around land use and the future of agriculture is discussed in the section on Core System Services-Access to Natural Resources.

\section{Socio-Cultural Norms}

Much of the discourse around socio-cultural norms is framed by the cultural importance of food, the complex relationship among people, food, and land, and the role of communitybased gardening, rather than the future of the agri-food industry providing economic or business opportunities. As part of the agri-food industry implications narrative, such discourse is not unexpected, given the relatively short history of commercialscale agriculture in the NWT relative to the very long standing Indigenous cultural ties to traditional foods from the land. There are concerns that an unsustainable agri-food industry could further diminish the role of the traditional food system. Traditional foods are inextricably linked to Indigenous culture and identity, as well as individual and community spiritual and physical well-being: "Country/traditional food has a critical place not only in the diet and health of the North, but also the maintenance of community, belonging, and inter-generational transfer of cultural practices and Traditional Knowledge and skills" (The Gordon Foundation, 2017, p.11). Myriad forces are driving socio-cultural changes that make it increasingly difficult for Indigenous communities to participate in traditional harvesting activities resulting in a decline in the consumption of traditional foods and increased consumption of ultra-processed imported market foods, which contribute to declining health. There is a sense of a loss of traditional food knowledge, which is seen as a loss of cultural identity (City of Yellowknife, 2019).

There is some question of the promise of the agri-food industry given the lack of traditional knowledge in growing food and the colonial legacy of agriculture. Others envision opportunities for agriculture to address food security and to open the possibility of "new" sources of traditional agri-food knowledge and "new" agri-food cultural practices. An illustrative example of this discourse can be seen in Simba and Spring (2017):

Some often question the appropriateness of agriculture as a solution in communities that have little to no background in growing food. Agriculture is a solution that non-Dene often bring into communities, with little involvement of locals. There is a legacy in many communities of gardens that have been planted by wellintentioned individuals from outside the community-gardens that never produced food because little education and support was provided to the community, and without community buy-in, no one took care of the garden. Nonetheless, growing food remains a potential solution that communities are interested in pursuing to meet their food needs, particularly with increasing costs of food and fuel... Planting the garden proved to be a very popular event in the community. Children from the school came out to help, as did some parents and Elders. In all, approximately 20 people, nearly half the community, turned out to take part in planting. In fact, the planting experience was captured on video in hopes of providing a how-to demonstration for other communities in the North. (p.26)

\section{Core System - Services Knowledge}

Within the context of the agri-food business case narrative, knowledge is prominent in the discourse about the promise of the agri-food industry in the NWT. Some see knowledge as a weakness, such that it is lacking, insufficient and inaccessible. There is a lack of local technical knowledge and expertise about agricultural production and food processing. There are no formal extension services in the NWT. Past agricultural knowledge has been lost [Cardinham Text and Creations, (n.d.)]. The existence and location of the records from the former experimental stations are uncertain. The importance of sharing knowledge is a common theme of the knowledge discourse. Others see knowledge as an opportunity to build a sustainable agri-food industry through research, innovation, training, and capacity building. Advances in northern agriculture science and technology are contributing to the potential for food to be grown and processed in the NWT. There is consensus that funding for innovation, research and knowledge dissemination is essential to meet the knowledge needs across the entire agri-food industry. The Aurora Research Institute and the Northern Farm Training Institute are considered important for the production and sharing of knowledge. This complex role of knowledge was captured in the GNWT's public engagement session for the Territorial agriculture strategy:

The most common theme during the "Challenges" section of all public engagement sessions was the need for the dissemination of knowledge about agricultural production. Even many of those actively growing food in some fashion now feel that they are underequipped in terms of technical expertise for field or greenhouse crop production. There is a clear need for both education and experience to be brought to all three sectors of the agriculture industry and the promise of the NFTI. Participants generally expressed excitement about the possibility that this organization will significantly increase the level of knowledge about agricultural production in the NWT... There was also discussion about the possibility of leveraging the Aurora Research Institute in similar ways. (Government of the 
Northwest Territories (Industry Tourism and Investment), 2015, p. 10)

\section{Inputs}

Agricultural inputs are resources used to increase yield, productivity, and quality of production whether for crops or livestock. Inputs include seeds, livestock feed, planting stock, fertilizer, plant or animal health protection products, soil amendments, utilities and equipment or machinery. In general, inputs are framed both negatively (weakness) and positively (opportunity), as part of the agri-food industry business case narrative. There is widespread agreement over the lack of and high costs of inputs. There are few agriculture dealers or input suppliers in the NWT. All agriculture inputs are imported from the south, making them very expensive due to transportation costs. They are often in short supply. However, a new rail line in Hay River is a promising opportunity for reducing the cost and increasing the availability of inputs. Due to the poor soil quality in the NWT, amendments such as fertilizers and compost are required to ensure proper crop growth and yield. In addition, raised beds are widely used to overcome the limitations of poor soil quality, which require lumber and some type of growing media (e.g., potting soil). The high cost and poor availability of livestock feed and health products are a barrier to future growth of the livestock sector. The barriers are not insurmountable. Commercial egg production and processing have been successful in the NWT for more than 10 years. There are several innovative solutions being considered for mitigating the input barriers to livestock production, specifically small animal production for meat (e.g., rabbits, chickens). The Hay River Agriculture Plan (Serecon, 2014), highlighted one such project:

\section{Small animals also require significant feed if they are to be raised at a commercial scale, but the cost of importing feed could perhaps be overcome with some creativity and adaptation of innovative practices. For example, one individual is currently implementing a barley fodder system, which will be used to rapidly grow barley seedlings, which are to be fed to rabbits and chickens initially. This type of system could significantly increase the volume of feed which could be grown on a limited land base. (p. 8)}

Utility costs are a barrier to extended season or year-round production (e.g., greenhouse), but also to long-term growth of the processing sector. Stakeholders in the consultation for the NWT Agriculture Strategy [Government of the Northwest Territories (Industry Tourism and Investment), 2015] identified two key issues:

[First], the possibility of power rates being specifically allocated for agricultural purposes, to increase the feasibility of longerseason operations and reduce the costs for starter greenhouses. [Second], "the possibility of access to waste heat generated by existing or planned community infrastructure, whether owned by the private or public sector. [Government of the Northwest Territories (Industry Tourism and Investment), 2015, p. 12].

Another challenge related to energy and the future of agriculture in the NWT is the implication for climate change of increased use of fossil fuels by an expanding agri-food industry, which is echoed in the ecosystems discourse. The opportunities to develop alternative energy sources, such as solar, wind, geothermal and biomass show great promise, but as yet are not a viable business option. This is an example of a theme being articulate through both dominant narratives.

Capital inputs, such as tractors, implements, irrigation systems and processing equipment are not only in short supply, but very expensive. The lack of agricultural financing in the NWT adds another dimension to the inputs barriers that limit the growth and development of the NWT agri-food industry. Neither banks nor agri-food financing institutions, such as the Farm Credit Corporation have adapted their financing procedures to reflect the unique social context of the NWT.

\section{Access to Natural Resources}

Access to suitable agricultural land is one of the subcomponents identified as having profound implications for the future of the agri-food industry in the NWT. The notion of "access" is complex and carries multiple, overlapping, interrelated meanings, which are linked to discourses about other subcomponents of the food system framework, such as soil and policy, regulation and governance. The discourse framing access to natural resources is another example that illustrates the two dominant narratives that emphasize the implications of the constraints and enablers of the food system on the future of the agri-food industry and the implications of an expanded agri-food industry on the NWT food system. Our analysis identified three key themes related to access to land.

\section{Lack of Infrastructure}

While there are regions of suitable agricultural land in some areas of the NWT, much of it is inaccessible due to the lack of roads or geographic barriers such as lakes. The use of heavy agricultural equipment will create new requirements for the design of future roads. Furthermore, accessing agricultural land may involve crossing through public or private tracts of land and will require access agreements.

\section{Unavailable for Production}

There are $\sim$ two million hectares of land deemed suitable for agriculture production in the NWT (GNWT, 2017). Much of this land is forested. It will require expensive, time consuming clearing, which has further implications for both climate change and ecosystem health. According to calculations done for the Hay River Agriculture Strategy (Serecon, 2014): “The cost of clearing, root raking and initial cultivation is ... likely in the range of $\$ 800-\$ 1,300$ per acre." (p. 14). There are concerns about public reactions to large areas of boreal forest being cleared for agrifood production, as well as the environmental and ecological implications related to the loss of biodiversity and habitats and the release of carbon from cleared land.

\section{Uncertainties Regarding Land Ownership}

Land ownership is a long-standing issue in the NWT. The uncertainties and limitations around land ownership are perceived as serious constraints for the future of the agrifood industry. Conventional, commercial-scale agriculture is 
grounded in notions of private property and land ownership. Without "title" to land, it is virtually impossible to get financing for agricultural operations. On the other hand, the notion of "owning" land is antithetical to Indigenous traditions. While the ownership of land storyline is included as part of "access to natural resources" key theme within the Core System-Activities component of the adapted food system framework (Figure 1), land ownership is also framed within the discourse about policy, regulations, and governance within the societal context. As highlighted by various stakeholders, land ownership is a complex and confusing issue that involves all levels of government and governance. Municipalities own land and can sell to private citizens. Land ownership outside municipal boundaries has inherent risks due to ongoing and outstanding land claims and treaty negotiations with Indigenous communities. Even crown (public) land is caught up in the discourses about land ownership. The following quotes illustrate the discourse that frames uncertainties regarding land ownership:

In the NWT, a complex and multi-level set of governance structures and relationships continues to evolve, most recently with the 2014 federal-to-territorial devolution of powers over public lands, waters and natural resources (Skinner et al., 2019, p. 5).

Given the complex nature of land ownership rules in the NWT, compounded with the recent devolution of responsibility for Crown land to the territory, as well as the myriad of ownership structures... (Serecon, 2014, p. 31).

The ownership structures for land in the NWT are varied and difficult to navigate if one is not familiar with the territorial and municipal registry systems (Serecon, 2014, p.34).

The GNWT acknowledges that the current land tenure system may not allow access to certain loan or funding programs available, and is committed to working to address this issue (GNWT, 2017, p. 13).

\section{Core System - Activities}

The core system activities represent the pathway through which food products are produced, which includes production, processing, distribution, consumption, and waste management. This is often referred to as the agri-food value-chain, which represents strategic partnerships among inter-dependent agrifood businesses who cooperate to incrementally create value by linking the core system activities to consumer needs.

\section{Production}

The production discourse is framed more positively than negatively, that is as strengths and opportunities, part of both dominant narratives. Within the agri-food industry implications narrative, there is a general sense of anticipation about the future of the agri-food industry to contribute to the core goals of the NWT food system-to fill gaps emerging in the traditional foods system and to reduce dependence on market foods. There is a sense that the agri-food industry represents entrepreneurial opportunities for poverty reduction, economic development and job creation. Agriculture was identified as an economic opportunity by the GNWT in 2013:
The Agriculture sector has grown dramatically over the past decade and now ranges from small community gardens to commercial greenhouses; regulated egg production, the harvesting of "wild" edibles, and the commercial harvest of game. Opportunities for future growth are broad and diverse... (Economic Opportunities Strategy Governance Committee, 2013,p. 64)

There are several key themes associated with production linked to the agri-food industry business case narrative. A diverse range of crops, mostly horticulture, are being successfully grown throughout the NWT. The high demand for local produce and current lack of competition within the value-chain is considered a driver that is enticing people to consider commercial-scale farming. There are few, if any, crop varieties developed for or adapted to the growing conditions of the NWT. Development of new northern crop varieties and production practices are identified as a promising opportunity. There are several research groups looking at long-term projects to develop northern adapted crops across Canada, which ties into the discourse around knowledge. Specific crops have been identified as promising, such as berries and a variety of greenhouse vegetables (Wohlgemuth, 2012). Urban agriculture is highlighted in the Yellowknife agriculture strategy as an opportunity for addressing various policy imperatives (City of Yellowknife, 2019). While the potential opportunities for livestock production are limited due mainly to issues related to the cost and availability of feed, egg production is thriving in the NWT. Smaller livestock such as meat chickens and rabbits are seen as promising agricultural ventures.

The high costs of production are framed as a threat in two ways. The first is tied to consumption and the lack of consumer awareness of the high cost of local production. Stakeholders noted that there is some resistance to pay more for local food than market food, which is already very expensive. Secondly, the high cost of production in the context of inputs threatens the ability of the production sector to compete with imported foods.

Another potential barrier in the production sector is weak value chain relationships. However, this could be seen as weakness across all of the core system activities, not just production. It is characterized by lack of understanding of the realities of value chain partners, which can lead to adversarial rather than collaborative value chain relationships.

A key theme of the production discourse linked to the agri-food industry implications narrative is the concern largely associated with agri-industrial systems defined by large-scale, commodity-based, monoculture production. However, it is highly unlikely that such an agri-industrial system will evolve in the NWT. The limitations of climate, suitable land, lack of interest by major agri-business players, the relatively small market and social-cultural values point to a unique agri-food industry in the NWT, unlike that of the more developed industries of the south. Most stakeholders envision an agri-food industry based on small-scale, diversified production, largely driven by entrerpreneurs focused on providing food from the NWT for the NWT. The idea of pursuing export markets for food from the NWT was virtually absent from the discourse on the promise of the agri-food industry. 


\section{Consumption}

Consumption is framed around the key themes of consumer demand and consumer preferences, which while overlapping are distinct drivers within the emerging NWT agri-food industry and linked to the agri-food industry business case narrative. Demand is positioned more quantitatively, representing the size of the market-the level of consumer demand for local food. There is consensus that demand is significantly higher than supply, with reports from vendors at farmers' markets and retailers that local products consistently sell out. Ecology North (Scott, 2014) estimated demand for fresh produce in the NWT at $\sim$ eight million kilograms, with a retail market value of $\mathrm{C} \$ 17$ million. Another aspect of consumption is the expectation that the agrifood industry will 'produce food in the NWT for the NWT'. There is little talk of building an export market that would compete with other more well-developed agri-food industries in the south. The focus is on supplying the NWT market and serving the core goals of the NWT food system.

Consumer preferences are a more qualitative discourse, representing the specific types and characteristics of local foods that consumers are looking for. Both are framed positively as strengths and opportunities. There is strong and growing demand for local food and consumers show a wide range of preferences for a variety of local food products. Consumers also show support for various market channels, such as direct sales (farmers' markets, farmgate) and local retailers. There is less agreement over whether consumers are willing to pay more for local products. Price insensitivity among consumers is cited by some stakeholders, while others have highlighted the lack of consumer awareness of the higher costs of local production as a barrier to the future of agriculture in the NWT. Some farmers have highlighted the struggle they face competing with "imported market food." The costs of local production make it a challenge to match the price of food in grocery stores (already significantly higher); farmers have faced resistance to the higher price of locally produced food. One farmer described it as a misconception about cost/price of local food.

\section{DISCUSSION}

Key to our findings are the two dominant narratives and key themes of the prevalent subcomponents of the FSF that emphasize both the constraints and enablers that will shape the future development of the nascent NWT agri-food industry (agrifood industry business case narrative), as well as the potential implications of an expanded agri-food industry on the NWT food system (agri-food industry implications narrative). The narratives and key themes are representative of the tensions and trade-offs that characterize the multiple intertwined objectives of food system transitions and values of food systems actors (Brouwer et al., 2020).

In this discussion, we complete our analysis of the NWT agrifood industry in the context of the FSF by linking our findings, which focused on the four outer rings of the FSF, to the two inner rings of the food system framework: sustainability and core goals (food security, nutrition, poverty reduction and economic development (Figure 1). We have combined food security with nutrition and economic development with poverty reduction in our discussion given the overlap between these pairs of food system goals. With this discussion we answer our second research question: Given the framings of the promise of the agri-food industry as described in the findings, how can it contribute to the sustainability of the NWT food system and to the goals of food security, poverty reduction, nutrition and economic development? We further identify key issues and policy priorities for stakeholders to consider in their ongoing discussions of the future of the agri-food industry in the NWT.

\section{Sustainablity}

Sustainability (environmental, social, economic) is widely acknowledged as a necessary precursor to achieving the core goals of a food system: food security, nutrition, poverty reduction and economic development (El Bilali et al., 2019). In this section, the discussion focuses on environmental sustainability as a critical concern for food system actors. Social and economic sustainability are captured in our discussion of the other core goals. Environmental sustainability is most clearly articulated in the soil and ecosystem discourses as part of the agri-food industry implications narrative.

Soil and available land are limiting elements for growth of the NWT agri-food industry. Most land with suitable soils for agricultural production is currently forested and will require clearing. Conversion from boreal forest to agriculture has consequences. Soils represent the largest pool of carbon within the boreal ecosystem (Pan et al., 2011; Bradshaw and Warkentin, 2015; Schuur et al., 2015). This means soils in the NWT act as a critical carbon sink. Studies have shown that land use change from forest to cropland has the potential to reduce existing carbon stocks by up to $42 \%$ (Guo and Gifford, 2002; Grünzweig et al., 2004). Grünzweig et al. (2004) noted that following forest to cropland conversion, soil carbon losses are greater in the boreal ecosystem than in other forest biomes. Without careful management, there is the risk that land conversion could potentially shift a significant carbon sink to a carbon source (Post and Kwon, 2000; Guo and Gifford, 2002). However, the amount of carbon loss in agricultural fields following cultivation is highly variable and dependent on factors such as climate, farming practices, hydrology, and topography (Compton and Boone, 2000; Post and Kwon, 2000). In addition, the conversion of forest to cropland has the potential to reduce the resiliency of the ecosystem to perturbations such as drought or soil erosion (Lal et al., 2004; Conant et al., 2011). Global climate models have projected agricultural expansion into high-latitude northern soils (King et al., 2018; Hannah et al., 2020), but these studies do not account for local soil conditions in determining what crops can be grown and where. There is a need for soil science research in the NWT to help inform regional models to better determine suitable areas for agriculture. Effective policies and field-scale soil management practices will be needed to improve the carbon sequestration potential of nascent agroecosystems and minimize carbon release. Targeted efforts for managing and protecting soil health will be necessary to ensure the environmental sustainability of the agri-food industry. 
The boreal forest is a source of traditional foods and serves significant historical, spiritual, and cultural roles for Indigenous populations and others who share the land (Government of the Northwest Territories, 2014). As land is seen as the basis of food systems in the NWT, agricultural practices and policies that protect the unique NWT ecosystem are needed. Sustainable agricultural practices that prioritize ecosystem health have gained wide acceptance in fragile and marginal environments and are aligned well with northern and Indigenous concepts of land stewardship and protection (Spring et al., 2019). The lack of an agri-food policy and regulatory framework could indeed be an opportunity to implement progressive, sustainable, climatesmart agricultural practices that protect the traditional food system for future generations. Implementing such policies early in the development of the agri-food industry is an opportunity for global leadership in co-designing a sustainable food system.

\section{Food Security and Nutrition}

Stability is a key piece of the food security puzzle in the NWT. The food system is vulnerable to inconsistent supply due to the reliance on imported market foods. For example, forest fires, which are expected to become more frequent due to climate change, have resulted in road closures, preventing food deliveries leading to food shortages in grocery stores (Dodd et al., 2018). The COVID-19 pandemic caused widespread disruption of global supply chains demonstrating the importance of strong local value chains. Expanding throughout the local value chain will help to counter the vulnerability to system shocks inherent in a food system that relies on imported foods. Increased food availability is linked to increased production but is also contingent upon getting the food to where it is needed. In this context, the development of distribution channels within the agri-food industry is critical to improving food security (Wittman et al., 2017).

Short, local value chains have been linked to increased nutrition security (Tomich et al., 2019). The production sector can contribute by selecting nutrient rich crop cultivars and varieties and adopting practices that enhance nutritional value. Currently, most of the food produced in the NWT are whole foods or have minimal processing, widely recognized in principle-based healthy eating recommendations that support both individual and public health (Health Canada, 2019; Willett et al., 2019). There are promising opportunities for value-added processing of both agricultural products and traditional foods to provide a diverse range of nutritious food products. Valueadded activities will also make nutritious local and traditional foods available throughout the year. The emerging agri-food industry therefore has the potential to alleviate some of the complex issues of nutrition insecurity in the NWT insofar as it is able to provide diverse, nutrient rich foods to support the well-being of residents. Along with contributions from the agri-food industry, social policies that ensure all residents have equitable access to affordable, nutritious, and culturally appropriate local food options will be necessary to reduce nutrition insecurity.

\section{Economic Development and Poverty Reduction}

Much emphasis is placed on the promise of the NWT agri-food industry as a driver of economic growth and diversification at the community and territorial level [Government of the Northwest Territories (Industry Tourism and Investment), 2015; GNWT, 2017]. The agri-food industry is recognized as an important economic driver in other northern regions of Canada (Caldwell et al., 2018). Expansion of the NWT agri-food industry will open new sources of economic growth and contribute to the socioeconomic health of communities. An important consideration for the promise of the agri-food industry to contribute to economic development include adapted financial instruments that address the barriers related to land ownership.

In order for agri-food businesses to support economic development, they must be competitive and profitable. They must be able to compete with imported market foods and they must be based on viable business models. As noted by Wilson et al. (2020), "the financial viability of northern farms is currently reliant on government support" (p. 298). Policy gaps noted in the results point to the need for made-in-the NWT regulations to support agri-food business viability and reduce operating costs. Supportive policies and practices such as zoning that permit residential and agricultural use, land use partnerships, food safety, business loans, and labor laws can provide the necessary infrastructure and security for agri-food businesses to succeed and thus contribute to economic development.

Indigenous engagement is especially relevant to economic development due to issues of land title and ownership in the NWT. With a mixture of settled and unsettled comprehensive land claims, devolution of land authority from federal to territorial and Indigenous self-government, land title is an ongoing issue that will have far reaching ramifications for the development of an agri-food industry in the NWT. Furthermore, the agri-food system transition may indeed look different from region to region. Similar to participation in commercial fisheries, local control of resources and direct community involvement in decision making and monitoring is important (Lowitt et al., 2020). The often-tense relationship fostered by agricultural development in Canada between Indigenous and settler communities is well-documented (Kepkiewicz and Dale, 2019).

There is evidence that agriculture is directly linked reducing poverty (Christiaensen et al., 2011). It is widely acknowledged that agriculture provides a livelihood for many people in developing economies (Tomich et al., 2019). Entrepreneurship and job creation across the value chain are some of the ways that the NWT agri-food industry will contribute to poverty reduction.

As a new economic sector, growth in the agri-food industry will be driven by entrepreneurship, that is individuals or communities starting up viable businesses around an identified need. While there are promising entrepreneurial opportunities in the NWT agri-food industry, there are barriers to building viable, profitable agri-businesses that support the livelihoods of operators and employees (GNWT, 2017; Wilson et al., 2020). The constraints noted in the results point to the need for a policy and governance framework to support entrepreneurship, startups, 
and new ventures. Investments in research and innovation are also necessary, as they have been linked to poverty reduction (Tomich et al., 2019).

The agri-food industry represents a new labor market for the NWT. Skilled labor is critical to the success of the industry. There currently is a shortage of skilled labor in the NWT agrifood industry. Continued expansion across the agri-food valuechain will further drive the need for skilled labor. The jobs created by the agri-food industry will have a direct impact on poverty reduction, through income growth, greater labor market participation and multiplier effects (Tomich et al., 2019).

The demand for skilled labor highlights the need for training capacity, which could be met from existing formal learning institutions and programs such as Aurora College, the Northern Farm Training Institute or through the actions of diverse actors who self-organize and form partnerships and mentorship networks (i.e., industry associations). The increased agri-food knowledge, skills, and community capital built through training can help support both commercial entrepreneurial opportunities and individual, family, and community subsistence ventures that will reduce poverty and also improve food security through better access to food in the NWT.

\section{CONCLUSION}

Using an adapted food systems framework (Figure 1), we described the diverse and sometimes conflicting ways in which food systems actors envision the promise of the emerging NWT agri-food industry in contributing to the core goals of the NWT food system. The study identified key opportunities and barriers impacting the agri-food industry as it is integrated into the existing food system. Importantly, we highlight the need for agri-food policies and governance frameworks that address how the emerging agri-food industry can potentially contribute to the goals of food security, economic development and sustainability of NWT food system. Much of this relies on building a system that complements, and even strengthen traditional food systems and relationships within and between Indigenous communities. This is an area that requires additional exploration and discussion, particularly around issues of land title and access.

Identifying, understanding, and managing trade-offs among multiple food system goals is a critical, but underexplored dimension of systems approaches to food system analysis (Brouwer et al., 2020). For food system actors working to establish effective strategies, programs, policies and governance structures, knowing how to identify and manage conflicts and competing values and balance various interests and priorities is important for achieving food system goals (Allen and Prosperi, 2016; Tribaldos et al., 2018). While a fully integrated synthesis of the dynamics and trade-offs among the NWT food system core goals is beyond the scope of this paper, we believe this work provides a critical empirical foundation for such analysis in the future.

The agri-food industry will soon play a more significant role in the NWT food system. What exactly this role is and how it will evolve, are still part of ongoing discussions that need time and patience as the industry grows and evolves. It is clear this transition is food sovereignty in action and supporting more inclusive dialog between all actors of the NWT food system is critical. A truly made-in-the NWT agri-food system has the potential to be an example of reconciliation and to represent an authentic approach to co-designing a sustainable food system that integrates Indigenous food cultures and traditions, an agri-food industry and community-based subsistence food production.

\section{DATA AVAILABILITY STATEMENT}

Requests for access to the datasets generated for this article should be directed to the corresponding author.

\section{ETHICS STATEMENT}

The studies involving human participants were reviewed and approved by the Ethics Review Board, Wilfrid Laurier University (REB \#4876).

\section{AUTHOR CONTRIBUTIONS}

ML conceived the study design and carried out the fieldwork the NWT, the SWOT and thematic analyses, completed the first draft of the Introduction, Materials and Methods and Results, contributed to the Discussion and Conclusion, integrated revisions of subsequent drafts, read, and approved the final manuscript. AS is principal investigator of the Northern Agriculture Future project and plays a supervisory role for $\mathrm{ML}, \mathrm{DB}$, and JR, contributed to all aspects of the manuscript in support of ML. JR participated one of the stakeholder engagement sessions, contributed to the SWOT analysis, drafted sections of the methods and discussion, completed full manuscript reviews and edits, compiled the references, read, and approved the final manuscript. DB contributed to the SWOT analysis, drafted sections on Northwest Territories climatic conditions, soil conditions, land use change impacts, and soil carbon, designed the adapted food systems framework figure (Figure 1), and the description of the framework components table (Table 1). All authors contributed to the article and approved the submitted version.

\section{FUNDING}

We gratefully acknowledge funding from the Climate Change Preparedness in the North (CCPN) and Climate Change Health Adaptation Program (CCHAP), both grands received by the Government of Canada (\#1819-NT-000101 and \#1920-NR-000646).

\section{ACKNOWLEDGMENTS}

We gratefully acknowledge the Ka'a'gee Tu First Nation, the Territorial Agrifood Association, and all our community partners in the NWT for their gracious participation in and support of our work. 


\section{REFERENCES}

Allen, T., and Prosperi, P. (2016). Modeling sustainable food systems. Environ. Manage. 57, 956-975. doi: 10.1007/s00267-016-0664-8

Bacon, C. M., Getz, C., Kraus, S., Montenegro, M., and Holland, K. (2012). The social dimensions of sustainability and change in diversified farming systems. Ecol. Soc. 17:art41. doi: 10.5751/ES-05226-170441

Bélisle, A. C., Wapachee, A., and Asselin, H. (2021). From landscape practices to ecosystem services: landscape valuation in indigenous contexts. Ecol. Econ. 179:106858. doi: 10.1016/j.ecolecon.2020.106858

Béné, C., Oosterveer, P., Lamotte, L., Brouwer, I. D., de Haan, S., Prager, S. D., et al. (2019). When food systems meet sustainability - Current narratives and implications for actions. World Dev. 113, 116-130. doi: 10.1016/j.worlddev.2018.08.011

Bradshaw, C. J. A., and Warkentin, I. G. (2015). Global estimates of boreal forest carbon stocks and flux. Global Planet. Change 128, 24-30. doi: 10.1016/j.gloplacha.2015.02.004

Braun, V., and Clarke, V. (2006). Using thematic analysis in psychology. Qual. Res. Psychol. 3, 77-101. doi: 10.1191/1478088706qp063oa

Brouwer, I. D., McDermott, J., and Ruben, R. (2020). Food systems everywhere: improving relevance in practice. Global Food Secur. 26:100398. doi: 10.1016/j.gfs.2020.100398

Caldwell, W., Epp, S., and Howes, K. (2018). Facilitating the Agricultural and Local Food Sector in Northern Ontario. Guelph, ON: University of Guelph.

Cardinham Text and Creations (n.d.). A History of the Development of Agriculture in the N.W.T. Territorial Farmers Association. Hay River, NT.

Chapman, M., Klassen, S., Kreitzman, M., Semmelink, A., Sharp, K., Singh, G., et al. (2017). 5 key challenges and solutions for governing complex adaptive (Food) systems. Sustainability 9:1594. doi: 10.3390/su9091594

Christiaensen, L., Demery, L., and Kuhl, J. (2011). The (evolving) role of agriculture in poverty reduction. An empirical perspective. J. Dev. Econ. 96, 239-254. doi: 10.1016/j.jdeveco.2010.10.006

City of Yellowknife (2019). GROW: Yellowknife Food and Agriculture Strategy. Available online at: https://www.yellowknife.ca/en/discovering-yellowknife/ resources/Foodies/Agriculture-Strategy/V3.0-GROW--YELLOWKNIFEFOOD-AND-AGRICULTURE-STRATEGY.pdf (accessed September 30, 2021).

Compton, J. E., and Boone, R. D. (2000). Long-term impacts of agriculture on soil carbon and nitrogen in New England forests. Ecology 81, 2314-2330. doi: 10.1890/0012-9658(2000)081<2314:LTIOAO >2.0.CO;2

Conant, R. T., Ryan, M. G., Ågren, G. I., Birge, H. E., Davidson, E. A., Eliasson, P. E., et al. (2011). Temperature and soil organic matter decomposition ratesSynthesis of current knowledge and a way forward. Global Change Biol. 17, 3392-3404. doi: 10.1111/j.1365-2486.2011.02496.x

Cook, D. (2017). Building Guide Your Soil: A Guide to Building Sustainable Garden Soil in the Northwest Territories. Yellowknife, NT: Ecology North. Available online at: https://ecologynorth.ca/wp-content/uploads/2020/02/BuildingYour-Soil-Guide.pdf (accessed September 30, 2021).

Council of Canadian Academies (2014). Aboriginal Food Security in Northern Canada: An Assessment of the State of Knowledge. The Expert Panel on the State of Knowledge of Food Security in Northern Canada, Council of Canadian Academies, Ottawa, ON, Canada.

Damman, S., Eide, W. B., and Kuhnlein, H. V. (2008). Indigenous peoples' nutrition transition in a right to food perspective. Food Policy 33, 135-155. doi: 10.1016/j.foodpol.2007.08.002

Dey, I. (1993). Qualitative Data Analysis: A User-Friendly Guide for Social Scientists. New York, NY : Routledge.

Dodd, W., Scott, P., Howard, C., Scott, C., Rose, C., Cunsolo, A., et al. (2018). Lived experience of a record wildfire season in the Northwest Territories, Canada. Canad. J. Public Health 109, 327-337. doi: 10.17269/s41997-018-0070-5

Dombroski, K., Diprose, G., Sharp, E., Graham, R., Lee, L., Scobie, M., et al. (2020). Food for people in place: reimagining resilient food systems for economic recovery. Sustainability 12:9369. doi: 10.3390/su12229369

Economic Opportunities Strategy Governance Committee (2013). Northwest Territories Economic Opportunities Strategy: connecting businesses and communities to economic opportunities. Available online at: https://www.iti.gov. nt.ca/sites/iti/files/0004-704_econ_opp_strat_-_low-res.pdf (accessed October 2, 2021).
El Bilali, H., Callenius, C., Strassner, C., and Probst, L. (2019). Food and nutrition security and sustainability transitions in food systems. Food Energy Secur. 8:e00154. doi: 10.1002/fes3.154

Food and Agriculture Organization of the United Nations (2018). FAO Sustainable Food Systems: Concept and Framework. Available online at: http://www.fao.org/ 3/ca2079en/CA2079EN.pdf (accessed September 30, 2021).

Galloway, T. (2014). Is the Nutrition North Canada retail subsidy program meeting the goal of making nutritious and perishable food more accessible and affordable in the North? Canad. J. Public Health 105, e395-e397. doi: 10.17269/cjph.105.4624

Gerlach, S. C., and Loring, P. A. (2013). Rebuilding northern foodsheds, sustainable food systems, community well-being, and food security. Int. J. Circumpolar Health 72:21560. doi: 10.3402/ijch.v72i0. 21560

GNWT (2017). Northwest Territories Agriculture Strategy: The Business of Food: A Food Production Plan 2017-2022. Available online at: https://www.iti.gov.nt.ca/ sites/iti/files/agriculture_strategy.pdf (accessed September 30, 2021).

Government of Newfoundland and Labrador (n.d.). The Way Forward on Agriculture: Sector Workplan. Available online at: https://www.gov.nl.ca/ffa/ files/Agriculture-Sector-Workplan_Final.pdf (accessed September 30, 2021).

Government of the Northwest Territories (2014). Northern Lands, Northern Leadership: The GNWT Land Use and Sustainability Framework. Available online at: https://www.lands.gov.nt.ca/sites/lands/files/resources/land_use_ and_sustainability_framework_updated_email.pdf (accessed September 30, 2021).

Government of the Northwest Territories (Industry Tourism and Investment) (2015). Towards a: Northwest Territories Agriculture Strategy: What We Learned. Available online at: https://www.iti.gov.nt.ca/sites/iti/files/ agriculture_strategy-_what_we_learned_report_2015.pdf (accessed September $30,2021)$.

Government of the Yukon (2016). Local Food Strategy for Yukon: Encouraging the Production and Consumption of Yukon-Grown Food 2016-2021. Available online at: https://yukon.ca/sites/yukon.ca/files/emr/emr-local-food-strategyfor-yukon.pdf (accessed September 30, 2021).

Grünzweig, J. M., Sparrow, S. D., Yakir, D., and Stuart Chapin, F. (2004). Impact of agricultural land-use change on carbon storage in Boreal Alaska. Global Change Biol. 10, 452-472. doi: 10.1111/j.1365-2486.2004.00738.x

Guo, L. B., and Gifford, R. M. (2002). Soil carbon stocks and land use change: a meta analysis: soil carbon stocks and land use change. Global Change Biol. 8, 345-360. doi: 10.1046/j.1354-1013.2002.00486.x

Hannah, L., Roehrdanz, P. R., Krishna Bahadur, K. C., Fraser, E. D. G., Donatti, C. I., et al. (2020). The environmental consequences of climate-driven agricultural frontiers. PLOS ONE 15:e0228305. doi: 10.1371/journal.pone.02 28305

Health Canada (2019). Canada's Dietary Guidelines for Health Professionals and Policy Makers. Available online at: https://food-guide.canada.ca/sites/default/ files/artifact-pdf/CDG-EN-2018.pdf (accessed September 30, 2021).

Hetherington, K. (2020). Agribiopolitics: the health of plants and humans in the age of monocrops. Environ. Plan. D. Soc. Space 38, 682-698. doi: $10.1177 / 0263775820912757$

Hodbod, J., and Eakin, H. (2015). Adapting a social-ecological resilience framework for food systems. J. Environ. Stud. Sci. 5, 474-484. doi: 10.1007/s,13412-015-0280-6

IPES-Food (2016). From Uniformity to Diversity: A Paradigm Shift From Industrial Agriculture to Diversified Agroecological Systems. Brussels: International Panel of Experts on Sustainable Food systems.

Johnston, C. (2018). Using Participatory Action Research to Support Civil Society Action for a Sustainable Food System in Yellowknife (M.A. thesis). Carleton University, Ottawa, ON, Canada.

Kepkiewicz, L., and Dale, B. (2019). Keeping 'our' land: property, agriculture and tensions between Indigenous and settler visions of food sovereignty in Canada. J. Peasant Stud. 46, 983-1002. doi: 10.1080/03066150.2018.1439929

King, M., Altdorff, D., Li, P., Galagedara, L., Holden, J., and Unc, A. (2018). Northward shift of the agricultural climate zone under 21st-century global climate change. Sci. Rep. 8:7904. doi: 10.1038/s41598-018-26321-8

Kuhnlein, H. V. (2015). Food system sustainability for health and wellbeing of Indigenous peoples. Public Health Nutr. 18, 2415-2424. doi: $10.1017 /$ S1368980014002961 
Kuhnlein, H. V., and Receveur, O. (2007). Local cultural animal food contributes high levels of nutrients for Arctic Canadian Indigenous adults and children. J. Nutr. 137, 1110-1114. doi: 10.1093/jn/137.4.1110

Lal, R., Griffin, M., Apt, J., Lave, L., and Morgan, M. G. (2004). Managing soil carbon. Science 304, 393-393. doi: 10.1126/science.1093079

Lamalice, A., Haillot, D., Lamontagne, M., Herrmann, T., Gibout, S., Blangy, S., et al. (2018). Building food security in the Canadian Arctic through the development of sustainable community greenhouses and gardening. Écoscience 2, 325-341, doi: 10.1080/11956860.2018.1493260

Lamine, C. (2014). Sustainability and resilience in agrifood systems: reconnecting agriculture, food and the environment: sustainability and resilience in agrifood systems. Sociologia Ruralis 55, 41-61. doi: 10.1111/soru.12061

Lowitt, K., Levkoe, C. Z., Spring, A., Turlo, C., Williams, P. L., Bird, S., et al. (2020). Empowering small-scale, community-based fisheries through a food systems framework. Mar. Policy 120:104150. doi: 10.1016/j.marpol.2020.104150

Neven, D. (2014). Developing Sustainable Food Value Chains: Guiding Principles. Food and Agriculture Organization of the United Nations. Available online at: http://www.fao.org/sustainable-food-value-chains/library/details/ en/c/265156/ (accessed September 30, 2021).

O’Reilly, K. (2012). Ethnographic Methods. London: Routledge. doi: $10.4324 / 9780203864722$

Oteros-Rozas, E., Ruiz-Almeida, A., Aguado, M., González, J. A., and Rivera-Ferre, M. G. (2019). A social-ecological analysis of the global agrifood system. Proc. Natl. Acad. Sci. 116, 26465-26473. doi: 10.1073/pnas.1912710116

Pan, Y., Birdsey, R. A., Fang, J., Houghton, R., Kauppi, P. E., Kurz, W. A., et al. (2011). A large and persistent carbon sink in the world's forests. Science 333, 988-993. doi: 10.1126/science.1201609

Patel, R. (2013). The long green revolution. J. Peasant Stud. 40, 1-63. doi: 10.1080/03066150.2012.719224

Popkin, B. M. (2002). An overview on the nutrition transition and its health implications: the Bellagio meeting. Public Health Nutr. 5, 93-103. doi: 10.1079/PHN2001280

Post, W. M., and Kwon, K. C. (2000). Soil carbon sequestration and land-use change: Processes and potential: soil carbon sequestration and land-use change. Global Change Biol. 6, 317-327. doi: 10.1046/j.1365-2486.2000.00308.x

Power, E. M. (2008). Conceptualizing food security for Aboriginal people in Canada. Canad. J. Public Health 99, 95-97. doi: 10.1007/BF03405452

Powlson, D. S., Gregory, P. J., Whalley, W. R., Quinton, J. N., Hopkins, D. W., Whitmore, A. P., et al. (2011). Soil management in relation to sustainable agriculture and ecosystem services. Food Policy 36, S72-S87. doi: 10.1016/j.foodpol.2010.11.025

Radcliffe, J., Skinner, K., Spring, A., Picard, L., Benoit, F., and Dodd, W. (2021). Virtual barriers: unpacking the sustainability implications of online food spaces and the Yellowknife Farmers Market's response to COVID-19. Nutr. J. 20:12. doi: 10.1186/s12937-021-00664-x

Schuur, E. A. G., McGuire, A. D., Schädel, C., Grosse, G., Harden, J. W., Hayes, D. J., et al. (2015). Climate change and the permafrost carbon feedback. Nature 520, 171-179. doi: 10.1038/nature14338

Scott, C. (2014). State of Agriculture Report- Agricultural Land Use Survey. Yellowknife, NT: Ecology North.

Serecon (2014). Hay River Agriculture Plan: A Comprehensive Strategy for Sustainable Agricultural Development. Available online at: https://hayriver. com/wp-content/uploads/2017/07/Town-of-Hay-River-Agriculture-Plan.pdf (accessed March 26, 2014).

Simba, M., and Spring, A. (2017). Growing a Garden in Kakisa. Ottawa ON: Northern Public Affairs. Available online at: http://www.northernpublicaffairs. ca/index/volume-5-issue-1/ (accessed September 30, 2021).

Skinner, K., Fresque-Baxter, J., Spring, A., and Wesche, S. (2019). Learning from and enhancing community capacity for climate change and food security (C\$FS) action in the NWT. A proposal to the Canadian Institutes of Health Research.

Soppela, P. (2018). Looking to Lapland's Past for a Sustainable Food Source. New York, NY: The Circle: Sustainable Development Goals. Available online at: https://arcticwwf.org/newsroom/the-circle/sustainable-development-goals/ looking-to-laplands-past-for-a-sustainable-food-source/ (accessed June 7, 2018).

Spring, A., Carter, B., and Blay-Palmer, A. (2018). Climate change, community capitals, and food security: building a more sustainable food system in a northern Canadian boreal community. Canad. Food Stud. 5, 111-141. doi: 10.15353/cfs-rcea.v5i2.199

Spring, A., Skinner, K., Simba, M., Nelson, E., Baltzer, J., Swanson, H., et al. (2019). "Taking care of the land," in Sustainable Food System Assessment: Lessons From Global Practice, eds A. Blay-Palmer, D. Conaré, K. Meter, A. Di Battista, and C. Johnston (London: Routledge), 63-67. doi: 10.4324/978042943 9896-3

Stake, R. E. (2010). Qualitative Research: Studying How Things Work. New York, NY: Guilford Press.

Tarasuk, V., Mitchell, A., and Dachner, N. (2016). Household Food Insecurity in Canada, 2014. Toronto, ON: Research to Identify Policy Options to Reduce Food Insecurity (PROOF). Available online at: https://proof.utoronto. ca/ (accessed September 30, 2021).

Tendall, D. M., Joerin, J., Kopainsky, B., Edwards, P., Shreck, A., Le, Q. B., et al. (2015). Food system resilience: defining the concept. Global Food Secur. 6, 17-23. doi: 10.1016/j.gfs.2015.08.001

The Gordon Foundation (2017). Recommendations on Country/Traditional Food From the Northern Policy Hackathon. Available online at: https:// gordonfoundation.ca/wp-content/uploads/2018/01/Northern-PolicyHackathon-Digital.pdf (accessed September 30, 2021).

Tomich, T. P., Lidder, P., Coley, M., Gollin, D., Meinzen-Dick, R., Webb, P., et al. (2019). Food and agriculture innovation pathways for prosperity. Agric. Syst. 172, 1-15. doi: 10.1016/j.agsy.2018.01.002

Tribaldos, T., Jacobi, J., and Rist, S. (2018). Linking sustainable diets to the concept of food system sustainability. Sustain. Agric. Healthy Ecosyst. 6, 71-84.

Unc, A., Altdorff, D., Abakumov, E., Adl, S., Baldursson, S., Bechtold, M., et al. (2021). Expansion of agriculture in northern cold-climate regions: a crosssectoral perspective on opportunities and challenges. Front. Sustain. Food Syst. 5:663448. doi: 10.3389/fsufs.2021.663448

Vlados, C. (2019). On a correlative and evolutionary SWOT analysis. J. Strat. Manag. 12, 347-363. doi: 10.1108/JSMA-02-2019-0026

Vlados, C., and Chatzinikolaou, D. (2019). Towards a restructuration of the conventional SWOT Analysis. Bus. Manag. Stud. 5:76. doi: $10.11114 /$ bms.v5i2.4233

Willett, W., Rockström, J., Loken, B., Springmann, M., Lang, T., Vermeulen, S., et al. (2019). Food in the anthropocene: the EAT-Lancet Commission on healthy diets from sustainable food systems. Lancet 393, 447-492. doi: 10.1016/S0140-6736(18)31788-4

Wilson, A., Levkoe, C., Andree, P., Skinner, K., Spring, A., Wesche, S., et al. (2020). Strengthening sustainable Northern Food Systems: federal policy constraints and potential opportunities. Arctic 73, 292-311. doi: 10.14430/arctic 70869

Wittman, H., Chappell, M. J., Abson, D. J., Kerr, R. B., Blesh, J., Hanspach, J., et al. (2017). A social-ecological perspective on harmonizing food security and biodiversity conservation. Reg. Environ. Change 17, 1291-1301. doi: 10.1007/s10113-016-1045-9

Wohlgemuth, D. (2012). Stimulating Commercial Berry Production in the NWT Capital Regoin. Yellowknife, NT: Ecology North.

Conflict of Interest: The authors declare that the research was conducted in the absence of any commercial or financial relationships that could be construed as a potential conflict of interest.

Publisher's Note: All claims expressed in this article are solely those of the authors and do not necessarily represent those of their affiliated organizations, or those of the publisher, the editors and the reviewers. Any product that may be evaluated in this article, or claim that may be made by its manufacturer, is not guaranteed or endorsed by the publisher.

Copyright (๑ 2021 Lemay, Radcliffe, Bysouth and Spring. This is an open-access article distributed under the terms of the Creative Commons Attribution License (CC $B Y)$. The use, distribution or reproduction in other forums is permitted, provided the original author(s) and the copyright owner(s) are credited and that the original publication in this journal is cited, in accordance with accepted academic practice. No use, distribution or reproduction is permitted which does not comply with these terms. 